\title{
Upregulation of Tumor Necrosis Factor- $\alpha$ Gene by Epstein-Barr Virus and Activation of Macrophages in Epstein-Barr Virus-infected T Cells in the Pathogenesis of Hemophagocytic Syndrome
}

\author{
Jong-Ding Lay, ${ }^{\S}$ Chao-Jung Tsao,‡ Jen-Yang Chen, " Marshall E. Kadin," and Ih-Jen Su^§ \\ *Department of Pathology and ${ }^{\ddagger}$ Department of Internal Medicine, National Cheng Kung University Hospital and College of Medicine,

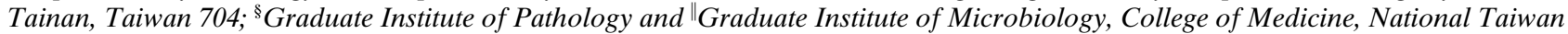 \\ University, Taipei, Taiwan 100; and "Department of Pathology, Beth Israel Deaconness Medical Center and Harvard Medical School, \\ Boston, Massachusetts 02115
}

\begin{abstract}
A potentially fatal hemophagocytic syndrome has been noted in patients with malignant lymphomas, particularly in EBV-infected $\mathrm{T}$ cell lymphoma. Cytokines, such as interferon- $\gamma$ (IFN- $\gamma)$, TNF- $\alpha$, and IL-1 $\alpha$, are elevated in patients' sera. To verify whether infection of T cells by EBV will upregulate specific cytokine genes and subsequently activate macrophages leading to hemophagocytic syndrome, we studied the transcripts of TNF- $\alpha$, IFN- $\gamma$, and IL- $1 \alpha$ in EBV-infected and EBV-negative lymphoma tissues. By reverse transcription PCR analysis, transcripts of TNF- $\alpha$ were detected in $8(57 \%)$ of $14 \mathrm{EBV}$-infected T cell lymphomas, higher than that detected in EBV-negative $\mathrm{T}$ cell lymphoma (one of six, 17\%), EBV-positive B cell lymphoma (two of five, $40 \%$ ) and EBV-negative B cell lymphomas (one of seven, $14 \%)$. Transcripts of IFN- $\gamma$ were consistently detected in $\mathrm{T}$ cell lymphoma and occasionally in B cell lymphoma, but were independent of EBV status. IL-1 $\alpha$ expression was not detectable in any category. Consistent with these in vivo observations, in vitro $\mathrm{EBV}$ infection of $\mathrm{T}$ cell lymphoma lines caused upregulation of TNF- $\alpha$ gene, and increased secretion of TNF- $\alpha$, but not IFN- $\gamma$ or IL-1 $\alpha$. Expression of TNF- $\alpha$, IFN- $\gamma$, and IL-1 $\alpha$ was not changed by EBV infection of B cell lymphoma lines. To identify the specific cytokine(s) responsible for macrophage activation, culture supernatants from EBV-infected T cells were cocultured with a monocytic cell line U937 for $24 \mathrm{~h}$. Enhanced phagocytosis and secretion of TNF- $\alpha$, IFN- $\gamma$, and IL-1 $\alpha$ by U937 cells were observed, and could be inhibited to a large extent by antiTNF- $\alpha$ (70\%), less effectively by anti-IFN- $\gamma(31 \%)$, but almost completely by the combination of anti-TNF- $\alpha$ and anti-IFN- $\gamma(85 \%)$. Taken together, the in vivo and in vitro observations suggest that infection of $T$ cells by EBV selectively upregulates the TNF- $\alpha$ expression which, in combination with IFN- $\gamma$ and probably other cytokines, can activate macrophages. This study not only highlights a probable
\end{abstract}

Address correspondence to Dr. Ih-Jen Su, Department of Pathology, National Cheng Kung University Hospital, 138, Sheng-Li Road, Tainan, Taiwan. Phone: 886-6-276-6695; FAX: 886-6-2766195.

Received for publication 28 January 1997 and accepted in revised form 18 August 1997.

J. Clin. Invest.

(C) The American Society for Clinical Investigation, Inc. 0021-9738/97/10/1969/11 \$2.00

Volume 100, Number 8, October 1997, 1969-1979

http://www.jci.org pathogenesis for virus-associated hemophagocytic syndrome, but also suggests that anti-TNF- $\alpha$ will have therapeutic potential in the context of their fatal syndrome. (J. Clin. Invest. 1997. 100:1969-1979.) Key words: tumor necrosis factor- $\alpha \cdot$ Epstein-Barr virus • T/NK cell lymphoma • hemophagocytic syndrome

\section{Introduction}

Hemophagocytic syndrome (HS) ${ }^{1}$ is a distinct clinicopathological entity characterized by fever, skin rashes, jaundice, hepatosplenomegaly, pancytopenia, and coagulopathy (1-5). The bone marrow, liver, spleen, and lymphoid organs of patients with HS are often diffusely infiltrated with lymphoid cells and phagocytic histiocytes (macrophages) (1-5). The consistent elevation of inflammatory cytokines in patients' sera, particularly TNF- $\alpha$, IFN- $\gamma$ and IL- $1 \alpha$, presumably released from the activated lymphoid cells and/or macrophages, has been suspected to be responsible for the pathogenesis of HS (6-12).

Many diseases have been reported to be associated with HS, particularly viral infection and malignant lymphoma (1-3). Among the infectious agents, EBV is most frequently implicated (2-4). Recently, a spectrum of benign and malignant T-lymphoproliferative disorders, i.e., childhood HS and T or T/natural killer (NK) cell lymphoma, have been demonstrated to be frequently associated with EBV infection, and manifest a high frequency of HS (13-19). The most striking and unexpected finding of these disorders is that EBV usually infects $\mathrm{T}$ lymphocytes, and only occasionally B cells $(2,17-20)$. In childhood HS and EBV-containing T cell lymphoma developing HS, activation of macrophages and phagocytosis is preceded by proliferation of activated or neoplastic T lymphocytes (4, 18, 21). Based on the temporal sequence of infiltrating cells in HS, infection of T lymphocytes by EBV appears to play a primary role in the subsequent activation and proliferation of macrophages $(16,18)$. Simrell et al. (6) first demonstrated that lymphokines released in angiocentric immunoproliferative disease, some of which have been currently presumed to be EBVcontaining T/NK cell lymphoma (22), induce phagocytosis. These observations raise the question of whether selective infection of $\mathrm{T}$ cells by EBV is responsible for subsequent macrophage activation and development of HS through the release of specific lymphokines in a manner similar to other herpes viruses $(23,24)$.

To elucidate the pathogenesis of HS in EBV-infected T

1. Abbreviations used in this paper: HS, hemophagocytic syndrome; NK, natural killer. 
lymphoproliferative disorders, and to identify the specific cytokines that are upregulated by EBV and are responsible for macrophage activation, we designed the following in vivo and in vitro experiments. First, we studied the expression of TNF- $\alpha$, IFN- $\gamma$ and IL- $1 \alpha$ genes in tissues of EBV-containing T/NK cell lymphomas, with comparison to other categories of malignant lymphomas. Second, in vitro EBV infection of CR2 (EBV receptor)-transfected $\mathrm{T}$ cell lymphoma lines was established, and expression and secretion of TNF- $\alpha$, IFN- $\gamma$, and IL- $1 \alpha$ were measured. Furthermore, we examined the effects of culture supernatants from EBV-infected $\mathrm{T}$ cells on the activation of macrophages and secretion of monokines in a monocytic cell line. The specific cytokine(s) responsible for macrophage activation was identified by neutralization of culture supernatants from EBV-infected T cells with cytokine-specific antibodies.

\section{Methods}

Tissue specimens of T cell and B cell lymphomas. Freshly frozen lymphoma specimens with adequate tissues for molecular studies were selected, including 14 cases of EBV-containing T or T/NK cell lymphomas (four nasal, one maxillary sinus, one larynx, one skin, one spleen, two intestine, and four lymph node) and six cases of EBVnegative $\mathrm{T}$ cell lymphoma (two skin, three lymph node, and one intestine). Additionally, five cases of EBV-containing B cell lymphoma (three Burkitt's lymphoma and two diffuse large cell lymphoma), and seven cases of EBV-negative diffuse large B cell lymphoma were simultaneously studied and used for comparison. Lymphoma specimens that contained a substantial percentage of reactive or nonneoplastic cells were excluded from this study. The immunophenotypic study and the status of EBV association have been previously characterized by immunohistochemistry and in situ hybridization with a probe specific for EBER1, an EBV-encoded early RNA $(16,18)$. The details of histology, immunophenotype, and EBV association of the 32 lymphoma cases are listed in Table I.

Cell lines. Two T cell lymphoma lines, H9 and HUT78, were used for in vitro EBV infection study. Both cell lines were derived from patients with CD4-positive T cell lymphoma, and no CR2 molecules were detected. For comparison, two B cell lines, BJAB and MC116, were studied simultaneously. The $\mathrm{BJAB}$ line was derived from an EBV-negative Burkitt's lymphoma, and the MC116 line from a diffuse large B cell lymphoma line. The B95.8 cell line is a marmoset EBV-containing B lymphoblastoid cell line derived by in vitro transformation with EBV obtained from the peripheral blood lymphocytes of a patient with infectious mononucleosis. B95.8 cells regularly release a type $1 \mathrm{EBV}$ strain, and were used as a source of virus for $\mathrm{T}$ and $\mathrm{B}$ cell infection in this study. For assay of phagocytosis, the human monocytic leukemia cell line U937, which has been proven to be a convenient system for studying monocyte/macrophage differentiation and function, was used (25).

$C R 2$ transfection and transient in vitro EBV infection of $T$ cell and $B$ cell lymphoma lines. Since H9 and HUT78 T cell lines do not express EBV receptor (CR2, CD21), a CR2-containing plasmid pSV2$\mathrm{CR} 2$ was transfected into both cell lines by electroporation method as previously described (26). The pSV2-CR2 plasmid carries the open reading frame of the $\mathrm{CR} 2 \mathrm{cDNA}$, and its expression is under the control of the SV40 promoter and the SV40 polyadenylation signal. This CR2 expression vector also contains the $\mathrm{Neo}^{\mathrm{r}}$ gene that can be used as a selection marker in stable transfection experiments. Before electroporation, exponentially growing cells were harvested by centrifugation and washed once with prechilled RPMI-1640 medium (JRH Biosciences, Lenexa, KS) without FBS, followed by electroporation buffer that consisted of $20 \mathrm{mM}$ Hepes buffer (JRH Biosciences), $137 \mathrm{mM}$ $\mathrm{NaCl}, 5 \mathrm{mM} \mathrm{KCl}, 0.7 \mathrm{mM} \mathrm{NaH}_{2} \mathrm{PO}_{4}$, and $0.6 \mathrm{mM}$ glucose. $2 \times 10^{6}$ cells were resuspended in $0.8 \mathrm{ml}$ of electroporation buffer, transferred to an electroporation cuvette (BTX Inc., San Diego, CA), and
$10 \mu \mathrm{g}$ of pSV2-CR2 plasmid DNA was added. The cuvettes were subjected to electroporation at the setting of $250 \mathrm{~V}$ and $960 \mu \mathrm{F}$ using an electro-cell manipulator $600^{\mathrm{TM}}$ (BTX Inc.). The resulting time constant for discharge of the capacitor was between 50 and $60 \mathrm{~ms}$ and the peak discharging voltage was $\sim 220-270 \mathrm{~V}$.

The transfected cells were subcultured in the drug selection medium containing $0.4 \mathrm{mg} / \mathrm{ml} \mathrm{G} 418$ (Sigma Chemical Co., St. Louis, MO) with thrice weekly feeding until the parental cells in negative control flasks died completely. After a 3-5 wk selection, cells were expanded with RPMI- 1640 plus $20 \%$ FBS for another 7 d. CR2 expression was then determined by flow cytometry using a FACSort ${ }^{\mathrm{TM}}$ machine (Becton Dickinson Labware, Franklin Lakes, NJ) and immunofluorescence assays were conducted using monoclonal mouse antihuman CR-2 antibody (HB-5 clone, type IgG2a; Becton Dickinson, Mountain View, CA), and the population of CR2-positive cells was determined.

The CR2-expressing T cell lymphoma lines were used directly for in vitro EBV infection experiments. The procedures for preparation and titration of cell-free EBV have been described previously (27). In brief replication of EBV was induced by culture of B95.8 cells at $2-5 \times$ $10^{6}$ cells $/ \mathrm{ml}$ in medium containing $10 \mathrm{ng} / \mathrm{ml}$ of $12-$ O-tetradecanoylphorbol-13-acetate (TPA) and $3 \mathrm{mM} n$-butyrate (Sigma Chemical Co.) for $3 \mathrm{~d}$. The cells and debris were removed, and the virus was pelleted by ultracentrifugation at $150,000 \mathrm{rpm}$ for $90 \mathrm{~min}$, filtered through a $0.8-\mu \mathrm{m}$ pore size filter (Costar Corp., Cambridge, MA) and then stored at $-20^{\circ} \mathrm{C}$. Titration of EBV was performed by limiting dilution method by analyzing the transformation efficiency on unfractionated mononuclear cells from human cord blood.

Successful infection of EBV was confirmed by in situ EBER1 hybridization as previously described $(16,17)$. A nonradioactive digoxigenin (DIG)-labeled probe was prepared by the random primed DNA labeling method using DIG DNA labeling and detection kits (Boehringer Mannheim, Mannheim, Germany). The entire labeling procedure was performed according to the manufacturer's instructions. Cytospin slides containing specimens that were fixed in $4 \%$ paraformaldehyde were treated with proteinase K $(100 \mathrm{mg} / \mathrm{ml}$, Sigma Chemical Co., St. Louis, MO) at $37^{\circ} \mathrm{C}$ for $15 \mathrm{~min}$. They were then acetylated, washed, dehydrated, and prehybridized at $42^{\circ} \mathrm{C}$ for $1 \mathrm{~h}$. The digoxigenin-labeled DNA probe was applied in the hybridization mixture (containing 50\% deionized formamide, $3 \times$ SSC, $10 \%$ dextran sulphate, $100 \mu \mathrm{g} / \mathrm{ml}$ salmon sperm DNA, and $1 \times$ Denhardt's solution ( $0.2 \%$ Ficoll, $0.2 \%$ BSA, $0.02 \%$ polyvinylpyrolidine) followed by incubation at $42^{\circ} \mathrm{C}$ for $16 \mathrm{~h}$. After hybridization, the slides were washed and submerged in buffer containing $0.1 \mathrm{M}$ maleic acid and $0.15 \mathrm{M}$ sodium chloride ( $\mathrm{pH} 7.5$ ) for $10 \mathrm{~min}$. Visualization of signals was carried out by incubation of antidigoxigenin alkaline phosphatase-conjugated Fab fragments in $4.5 \mu$ l nitobluetetrazolium salt and $3.5 \mu \mathrm{l} \mathrm{X}$-phosphate solution (Boehringer Mannheim) at $37^{\circ} \mathrm{C}$ for $1 \mathrm{~h}$. Sense-strand DNA probes were used as negative controls.

To verify the specificity of EBV infection of CR2-transfected T cells, UV-irradiated viral particles were used as control for infection of CR2-transfected $\mathrm{T}$ cell lymphoma lines. $0.2 \mathrm{ml}$ of cryopreserved B95.8 strain EBV stock was rapidly thawed and transferred to a 5-cm Petri dish, and then irradiated for 15 min with a $30-\mathrm{W}$ germicidal ultraviolet lamp (Hanovia Lamps) at a distance of $40 \mathrm{~cm}$. The virus was then immediately used for the infection experiment.

RNA extraction and semiquantitative RT-PCR analysis for cytokine gene expression. To detect the transcripts of cytokine genes in lymphoma tissues and cell lines, total cellular RNA, either from six $10-\mu \mathrm{m}$ frozen sections of lymphoma tissues, or from $\sim 10^{7}$ viable cells of lymphoma lines at different time points of EBV infection, was isolated by a modified rapid guanidium isothiocyanate method (28). To eliminate residual genomic DNA from RNA samples, $1 \mu \mathrm{g}$ of total RNA was incubated with $0.1 \mathrm{U}$ RNase-free DNase, added with $5 \mathrm{U}$ of RNAsin (GIBCO BRL, Gaithersburg, MD), extracted by phenol/ chloroform and redissolved in DEPC-treated water. The quality of extracted RNA was checked by agarose gel electrophoresis.

Conversion of total RNA into first-strand cDNA was performed 
by using the SuperScript ${ }^{\mathrm{TM}}$ II Preamplification System (BRL, New York, NY). In brief, $2 \mu \mathrm{g}$ of RNA mixture was heated at $70^{\circ} \mathrm{C}$ for 10 min, and quick-chilled on ice. After collection by brief centrifugation, the reverse transcription reaction mixture that contained $200 \mathrm{U} \mathrm{Su}-$

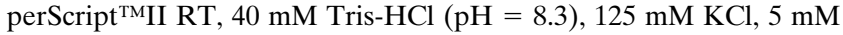
$\mathrm{MgCl}_{2}, 0.2 \mathrm{mg} / \mathrm{ml}$ BSA, $1 \mu \mathrm{l}$ oligo $(\mathrm{dT})_{12-18}(500 \mu \mathrm{g} / \mathrm{ml}), 10 \mathrm{mM} \mathrm{dNTP}$ mixture, and 0.1 M DTT, was added to the RNA, followed by incubating at room temperature for $10 \mathrm{~min}$. The tubes were further incubated at $42^{\circ} \mathrm{C}$ for $50 \mathrm{~min}$ and the reaction was terminated by incubating at $90^{\circ} \mathrm{C}$ for $5 \mathrm{~min}$. After chilling on ice for $10 \mathrm{~min}$, the reaction mixture was incubated with $10 \mathrm{U}$ RNaseH solution at $37^{\circ} \mathrm{C}$ for $20 \mathrm{~min}$ to remove RNA template. The synthesized cDNA was then used in a PCR amplification procedure.

Several pairs of primers specific for cytokine genes were used for PCR amplification, and their nucleotide sequences are listed as follows: TNF- $\alpha, 5^{\prime}$ primer (5'-CCCTCAAGCTGAGGGGCAGCTCCAG-3') and $3^{\prime}$ primer (5'-GGGCAATGATCCCAAAGTAGACCTG-3'), amplifying a PCR product of $220 \mathrm{bp}$; IFN- $\gamma, 5^{\prime}$ primer (5'-TGGAAAGAGGAGAGTGACAG-3') and $3^{\prime}$ primer (5'-ATTCATGTCTTCCTTGATGG-3'), amplifying a PCR product of 129 bp; IL-1 $\alpha, 5^{\prime}$ primer ( $5^{\prime}$-ATGGCCAAAGTTAGATGTTTG-3') and $3^{\prime}$ primer (5'-GGTTTTCCAGTATCTGAAAGTCAGT-3'), amplifying a PCR product of $816 \mathrm{bp} ; \beta$-actin, $5^{\prime}$ primer $\left(5^{\prime}\right.$-ATCATGTTTGAGACCTTCAA-3') and $3^{\prime}$ primer (5'-CATCTCTTGCTCGAAGTCCA-3'), amplifying a PCR product of $310 \mathrm{bp}$. To standardize the amount of cDNA input in each amplification, control amplification for $\beta$-actin gene was run simultaneously in each reaction. $10 \mu \mathrm{l}$ of the cDNA, $10 \mathrm{mM}$ Tris- $\mathrm{HCl}\left(\mathrm{pH}=8.8\right.$ at $\left.25^{\circ} \mathrm{C}\right), 1.5$ $\mathrm{mM} \mathrm{MgCl} 2,50 \mathrm{mM} \mathrm{KCl}, 0.1 \%$ Triton X-100, $2 \mu \mathrm{l}$ of amplification primer pair (10 $\mu \mathrm{M}$ each), $2 \mathrm{U}$ of DyNAZyme ${ }^{\mathrm{TM}}$ II DNA polymerase (from DyNAZyme ${ }^{\mathrm{TM}}$ II PCR kit; Finnzymes Oy, Riihitontuntie, Finland) and distilled water were overlayed with mineral oil and subjected to 30 rounds of PCR amplification with a DNA thermal cycler (Perkin Elmer Corp., Norwalk, CT). The amplification protocol is as follows: $94^{\circ} \mathrm{C}$ for $1 \mathrm{~min}, 58^{\circ} \mathrm{C}$ for $2 \mathrm{~min}$, and $72^{\circ} \mathrm{C}$ for $1 \mathrm{~min}$. After amplification, $10 \mu \mathrm{l}$ of the sample was analyzed with $2 \%$ agarose gel electrophoresis.

The intensity of the PCR products was determined by laser densitometry. For each sample, the amount of cytokine mRNA was quantified relative to the respective level of $\beta$-actin mRNA. In lymphoma tissue, the abundance of the respective mRNA was expressed in a relative manner as OD of cytokine mRNA:OD of $\beta$-actin mRNA of the same sample. For the EBV-infected cell lines, the given ratio was compared to the one obtained in uninfected cells using the following formula: (OD of cytokine mRNA/OD of $\beta$-actin mRNA of the sample)/(OD of cytokine mRNA/OD of $\beta$-actin mRNA of uninfected cells) $=$ relative mRNA density. RT-PCR experiments were repeated three times, and the reproducibility was confirmed. All PCR reactions were carried out in conditions in which amplification was linear by using serial concentrations of $\beta$-actin mRNA to construct a standard curve. Negative controls including PCR reagents without sample DNA, and PCR reagents plus genomic DNA without RT reaction, showed no specific signal.

ELISA of TNF- $\alpha, I F N-\gamma$, and IL-1 $\alpha$ secretion in the culture supernatant. To examine the effect of EBV infection on the regulation of cytokine secretion, secreted cytokine levels obtained at different time points from culture supernatants of EBV-infected T cells were measured by an ELISA method. Monoclonal antibodies that react with specific epitopes on TNF- $\alpha$, IFN- $\gamma$, and IL- $1 \alpha$ molecules were used in the ELISA tests (Bender MedSystems, Vienna, Austria). Aliquots of the volume of the supernatants of EBV-infected T cells at each time point of EBV infection were obtained from $10^{6}$ viable cells. Supernatants were harvested by filtration through a $0.45-\mu \mathrm{m}$ pore size filter (Costar Corp., Cambridge, MA) to exclude cell debris. The clear filtrate was kept at $4^{\circ} \mathrm{C}$ and assayed as soon as possible. The test sample or serially diluted recombinant cytokines at various concentrations as external standards were added to different wells in duplicate, and were incubated on a rotor set at $100 \mathrm{rpm}$ at room temperature for $2 \mathrm{~h}$.
After washing with PBS containing 1\% Tween 20, the bound cytokines were detected by horseradish peroxidase-conjugated anti-TNF- $\alpha$, anti-IFN- $\gamma$, or anti-IL- $1 \alpha$ mAbs, followed by incubation with $50 \%$ tetramethyl-benzidine as chromogenic substrate with $0.02 \%$ buffered hydrogen peroxide for $30 \mathrm{~min}$. The enzyme reaction was stopped by rapidly adding $100 \mu \mathrm{l}$ of stop solution containing $0.18 \mathrm{M}$ sulfuric acid, and the absorbance of each microwell was read in an ELISA spectrophotometer using $450 \mathrm{~nm}$ as the primary wavelength and $620 \mathrm{~nm}$ as the reference wavelength. The average absorbance values for each set of duplicate standards and samples were calculated. Duplicates were always within $20 \%$ of the mean. A standard curve was created by plotting the mean absorbance for each standard concentration. The sensitivity of the ELISA was $1.5 \mathrm{pg} / \mathrm{ml}$ for TNF- $\alpha, 1.5 \mathrm{pg} / \mathrm{ml}$ for IFN- $\gamma$, and $0.2 \mathrm{pg} / \mathrm{ml}$ for IL- $1 \alpha$.

Phagocytosis assay and monokine secretion of monocytic cell line U937 after treatment with supernatants of EBV-infected T cells. The CR2-transfected H9 or HUT78 T cell lymphoma lines were infected with EBV, and the culture media were then collected at 0,24 , and $72 \mathrm{~h}$ after EBV infection. Aliquot amounts of culture medium from $5 \times$ $10^{6}$ viable cells at each time point were then sampled to treat the monocytic cell line U937. Because untreated U937 cells were rather undifferentiated and not activated, they exhibited little or no spontaneous phagocytic activity (25). To increase the phagocytic activity, U937 cells were stimulated with $5 \mathrm{ng} / \mathrm{ml}$ TPA for $2 \mathrm{~d}$, and the slightly adherent cells were collected for the following phagocytosis assays. A total of $2.5 \times 10^{6} \mathrm{U} 937$ monocytic cells were then cocultured with culture supernatants from EBV-infected T cells. After coculturing for $24 \mathrm{~h}$, the cultured monocytic cells were then washed three times with PBS to remove the supernatants. The monocytic cells were then cultured further in RPMI-1640 in 24-well plates $\left(2 \times 10^{5}\right.$ cells $/ \mathrm{ml} /$ well $)$ for another $48 \mathrm{~h}$, and were prepared for phagocytosis assay. To determine the phagocytic activity, cells were then coincubated with $10^{8} / \mathrm{ml}$ (0.78- $\mu \mathrm{m}$ diameter) FITC-labeled latex beads (Fluoresbrite, Polysciences, Warrington, PA) for $2 \mathrm{~h}$. After washing the cells four times with $5 \mathrm{ml}$ PBS to remove undigested beads, the percentage of cells that engulfed latex beads was counted by flow cytometry using a FACSort machine (Becton Dickinson Labware) and analyzed in histograms using the LYSIS 2 Ver 1.1 program (Becton Dickinson). The morphology of phagocytic activity was examined with fluorescence microscopy. The secretion of monokines TNF- $\alpha$, IFN- $\gamma$, and IL- $1 \alpha$ from the activated monocytic cells was assayed in parallel by ELISA test as described above.

Blockade of phagocytosis and cytokine secretion in activated monocytic cells by treatment of culture supernatant from EBV-infected $T$ cells with anti-TNF- $\alpha$ and/or anti-IFN- $\gamma$. To identify the specific cytokine(s) in culture media of EBV-infected T cells leading to enhanced phagocytotic activity, the culture supernatant of EBV-infected T cells was treated with anti-TNF- $\alpha$ and anti-IFN- $\gamma$, either alone or in combination, before coculturing with monocytic cells. The polyclonal anti-human TNF- $\alpha$ and IFN- $\gamma$ neutralizing antibodies (R\&D Systems, Minneapolis, MN) were produced in goats immunized with purified, Escherichia coli-derived recombinant human TNF- $\alpha$ and IFN- $\gamma$. According to the manufacturer's description, anti-TNF- $\alpha$ at $0.02 \mu \mathrm{g} / \mathrm{ml}$ and anti-IFN- $\gamma$ at $7 \mu \mathrm{g} / \mathrm{ml}$ could neutralize $50 \%$ of the biological activity of $0.25 \mathrm{ng} / \mathrm{ml}$ of rTNF- $\alpha$ and $5 \mathrm{ng} / \mathrm{ml}$ of rIFN- $\gamma$ in a neutralizing bioassay using L929 cells. In this study, 5-ml of culture supernatants obtained from $5 \times 10^{6} \mathrm{cell} / \mathrm{ml} \mathrm{H} 9$ or HUT78 T lymphoma cells after 0,24, and $72 \mathrm{~h}$ of EBV infection was preincubated with $1 \mathrm{ml}$ $(50 \mu \mathrm{g} / \mathrm{ml})$ of anti-TNF- $\alpha, 1 \mathrm{ml}(20 \mu \mathrm{g} / \mathrm{ml})$ of anti-IFN- $\gamma$, or in a combination $(50 \mu \mathrm{g}$ anti-TNF- $\alpha$ and $20 \mu \mathrm{g}$ anti-IFN- $\gamma$ in $1 \mathrm{ml})$ for $37^{\circ} \mathrm{C}$. After $2 \mathrm{~h}$ of incubation, this medium was added to $5 \mathrm{ml}\left(5 \times 10^{5}\right.$ cells/ $\mathrm{ml}$ ) of monocytic cell line U937 for $24 \mathrm{~h}$. The monocytic cells were then washed three times with PBS to remove the supernatants, and were cultured further in supplemented RPMI-1640 for another $48 \mathrm{~h}$. The phagocytosis assay and ELISA test of monokine secretion were then repeated as described above. To exclude the possibility of direct effect of these antibodies on monocytic cells, the U937 cells were treated with antibodies directly as controls in each study. 


\section{Results}

Histopathology, immunophenotype, and EBV association. As shown in Table I, the EBV-containing T cell lymphomas expressed the immunophenotypes either of classical mature $\mathrm{T}$ cells (CD4+, six cases; CD8+, two cases) or of T/NK cells (CD4-/CD8-/CD56+, six cases) with heterogeneous tissue tropism. The EBV-negative $\mathrm{T}$ cell lymphomas were mostly of classical $\mathrm{T}$ cell lineage (CD4+, five cases; Ki-1+ lymphoma, one case), arising from skin, lymph node, and intestine. The EBV-positive B lymphomas included three cases of Burkitt's type lymphoma, and two diffuse large B cell lymphomas. The EBV-negative B cell lymphomas included 1 Burkitt's lymphoma and six diffuse large cell lymphomas of intestine, tonsil, stomach, and lymph node. In this series, four patients developed HS, and all belonged to the category of EBV-containing
T (case 1, CD4+; case 13, CD8+) or T/NK (cases 4 and 6) cell lymphoma. Significant infiltration of reactive macrophages with hemophagocytosis could be demonstrated in biopsy specimens in case 1 (skin) and case 13 (spleen).

Expression of cytokine genes in $T$ cell and B cell lymphoma tissues by semiquantitative RT-PCR analysis. As shown in Fig. 1 and Table I, among the 14 cases of EBV-positive T cell lymphoma, 8 cases $(57 \%)$ had detectable TNF- $\alpha$ transcripts, and all 14 cases $(100 \%)$ expressed IFN- $\gamma$. Among the six cases of EBV-negative $\mathrm{T}$ cell lymphoma, TNF- $\alpha$ transcripts were detected in only one case $(17 \%)$, and IFN- $\gamma$ transcripts were detected in all six cases $(100 \%)$. For EBV-positive B cell lymphoma, TNF- $\alpha$ transcripts were detected at low levels in two of five cases $(40 \%)$, and IFN- $\gamma$ was detected in two of five. In seven cases of EBV-negative B cell lymphoma, TNF- $\alpha$ tran-

Table I. Pathology, EBV Status, and Cytokine Gene Expression in EBV-positive and Negative T Cell and B Cell Lymphoma

\begin{tabular}{|c|c|c|c|c|c|c|}
\hline Case & Lineage & EBER1 & TNF- $\alpha$ & $\mathrm{IFN}-\gamma$ & IL-1 $1 \alpha$ & Site and type of lymphoma \\
\hline \multicolumn{7}{|c|}{ EBV-positive $T$ cell lymphoma } \\
\hline $1 *$ & $\mathrm{~T}(\mathrm{CD} 4)$ & + & $+\frac{+}{+}$ & + & - & Skin, diffuse large cell \\
\hline 2 & $\mathrm{~T}(\mathrm{CD} 4)$ & + & - & + & - & LN, diffuse medium-sized cell \\
\hline 3 & $\mathrm{~T}(\mathrm{CD} 8)$ & + & ++ & + & - & LN, diffuse, large cell \\
\hline $4 *$ & T/NK & + & ++ & + & - & Nasal, large cell \\
\hline 5 & $\mathrm{~T} / \mathrm{NK}$ & + & ++ & ++ & - & Nasal, large cell, relapsing \\
\hline $6^{*}$ & $\mathrm{~T} / \mathrm{NK}$ & + & ++ & ++ & - & Nasal, pleomorphic large cell \\
\hline 7 & $\mathrm{~T} / \mathrm{NK}$ & + & - & + & - & Maxillary sinus, mixed cell \\
\hline 8 & $\mathrm{~T} / \mathrm{NK}$ & + & + & + & - & Larynx, medium-sized cell \\
\hline 9 & $\mathrm{~T}(\mathrm{CD} 4)$ & + & - & + & - & $\mathrm{LN}$, large cell \\
\hline 10 & $\mathrm{~T}(\mathrm{CD} 4)$ & + & - & + & - & LN, large cell \\
\hline 11 & $\mathrm{~T}(\mathrm{CD} 4)$ & + & - & + & - & Intestine, large cell \\
\hline 12 & $\mathrm{~T} / \mathrm{NK}$ & + & - & + & - & Nasal, medium-sized cell \\
\hline $13^{*}$ & $\mathrm{~T}(\mathrm{CD} 8)$ & + & + & + & - & Spleen, diffuse large cell \\
\hline 14 & $\mathrm{~T}(\mathrm{CD} 4)$ & + & + & + & - & Intestine, large cell \\
\hline \multicolumn{7}{|c|}{ EBV-negative T cell lymphoma } \\
\hline 1 & $\mathrm{~T}(\mathrm{CD} 4)$ & - & - & ++ & - & LN, medium-sized cell \\
\hline 2 & $\mathrm{~T}(\mathrm{CD} 4)$ & - & - & + & - & Intestine, large cell \\
\hline 3 & $\mathrm{~T}(\mathrm{CD} 4)$ & - & + & ++ & - & $\mathrm{LN}, \mathrm{ATL}$ \\
\hline 4 & $\mathrm{~T}(\mathrm{CD} 4)$ & - & - & ++ & - & Skin, medium-sized cell \\
\hline 5 & $\mathrm{~T}(\mathrm{CD} 45 \mathrm{RO})$ & - & - & ++ & - & Skin, large cell, Ki-1 positive \\
\hline 6 & $\mathrm{~T}(\mathrm{CD} 4)$ & - & - & ++ & - & LN, diffuse large cell \\
\hline \multicolumn{7}{|c|}{ EBV-positive B cell lymphoma } \\
\hline 1 & B & + & - & ++ & - & BL, ovary \\
\hline 2 & $\mathrm{~B}$ & + & - & - & - & $\mathrm{BL}$, intestine \\
\hline 3 & $\mathrm{~B}$ & + & - & - & - & $\mathrm{BL}, \mathrm{LN}$ \\
\hline 4 & $\mathrm{~B}$ & + & + & ++ & - & DLCL, LN \\
\hline 5 & B & + & + & - & - & DLCL, LN \\
\hline \multicolumn{7}{|c|}{ EBV-negative B cell lymphoma } \\
\hline 1 & $\mathrm{~B}$ & - & - & ++ & - & $\mathrm{BL}$, intestine \\
\hline 2 & B & - & - & + & - & DLCL, LN \\
\hline 3 & B & - & - & - & - & DLCL, LN \\
\hline 4 & B & - & - & - & - & DLCL, LN \\
\hline 5 & B & - & + & - & - & DLCL, stomach \\
\hline 6 & B & - & - & + & - & DLCL, LN \\
\hline 7 & B & - & - & + & - & DLCL, tonsil \\
\hline
\end{tabular}

* Cases that presented with hemophagocytic syndrome. ${ }^{\ddagger}$ Symbols indicated the abundance of the respective mRNA: - , no mRNA discernible (OD of cytokine mRNA/OD of $\beta$-actin mRNA $\leq 0.1) ;+$, mRNA readily detectably (OD of cytokine mRNA/OD of $\beta$-actin mRNA $=0.1-0.5$ );,++ high steady-state levels of mRNA (OD of cytokine mRNA/OD of $\beta$-actin mRNA $\geq 0.5$ ). LN, lymph node; ATL, HTLV-1-positive adult T cell lymphoma; BL, Burkitt's lymphoma; DLCL, diffuse large cell lymphoma. 
$\mathbf{A}$
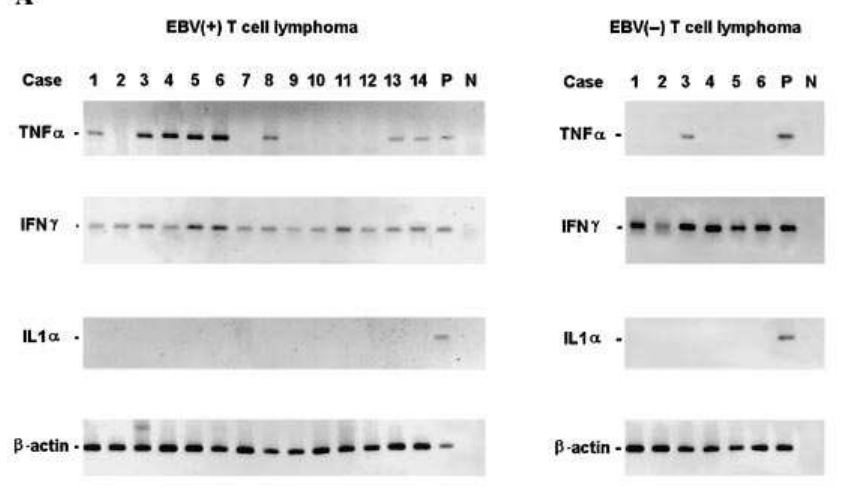

B

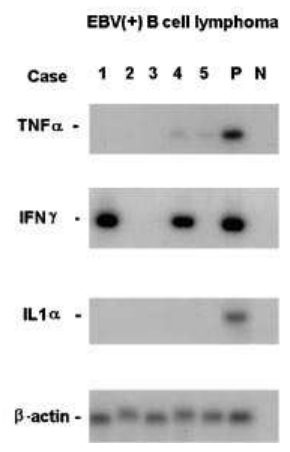

Figure 1. Transcripts of TNF- $\alpha$, IFN- $\gamma$, IL- $1 \alpha$ and $\beta$-actin genes analyzed by RT-PCR method on EBV-positive and negative T cell $(A)$ and $\mathrm{B}$ cell $(B)$ lymphoma specimens. The pathological diagnosis and relative mRNA densities of each case is given in Table I. P, positive control by using cDNA of H9 T cells; N, negative control, PCR reagents without DNA sample. $\beta$-actin transcripts were used as internal standard to determine relative expression of cytokine genes.

scripts were detectable in one (14\%), and IFN- $\gamma$ in four $(57 \%)$. No IL-1 $\alpha$ transcripts could be detected in any case of either category. Taken together, TNF- $\alpha$ transcripts were more often demonstrated in EBV-positive T or T/NK cell lymphoma when compared with the EBV-negative tumors and with B cell lymphomas. IFN- $\gamma$ was consistently expressed and IL-1 $\alpha$ was consistently undetectable in all $\mathrm{T}$ cell lymphomas, regardless of EBV status. These patterns of cytokine expression were not apparently affected by the sites of tumor presentation. Note that in all four patients developing HS, the tumor cells produced TNF- $\alpha$ as well as IFN- $\gamma$ (Table I).

In vitro transient $E B V$ infection of $B$ cell and CR2-transfected $T$ cell lymphoma lines. To determine whether EBV plays a differential role in regulation of cytokine genes in malignant lymphomas, an in vitro model of transient EBV infection was established for CR2-transfected T cell lymphoma lines and for CR2-positive B cell lymphoma lines. Expression of CR2 molecules was not detected in parental $\mathrm{T}$ cell lymphoma lines $\mathrm{H} 9$ and HUT78. After 4 wk of CR2 transfection and drug selection, $33 \%$ of $\mathrm{H} 9$ cells and $40 \%$ of HUT78 cells expressed CR2 molecules by flow cytometry. Both B cell lymphoma lines, BJAB (49\%) and MC116 (58\%), expressed CR2 molecules endogenously. Both the CR2-transfected T cell lines and CR2expressed B cell lymphoma lines could be successfully infected with EBV, as confirmed by in situ hybridization with EBER1 probe (Fig. 2). After $3 \mathrm{~d}$ of EBV infection, $11 \%$ of CR2-transfected H9 and 18\% of CR2-transfected HUT78 expressed nuclear EBER1 (Fig. 2, $g$ and $k$ ). As control, 38\% of EBVinfected BJAB cells (Fig. $2 c$ ) and $25 \%$ of EBV-infected MC116 cells also expressed EBER1 on the third day after infection. EBER1 was not detected in parental H9 or HUT78 $\mathrm{T}$ cells before EBV infection, nor in CR2-transfected $\mathrm{H} 9$ and HUT78 cells and B cell lines exposed to UV-inactivated EBV. The results indicate that EBV can specifically infect CR2-transfected $\mathrm{T}$ cell and CR2-expressing B cell lymphoma lines.

Enhanced expression of TNF- $\alpha$ gene by in vitro EBV infection of CR2-transfected $T$ cell, but not B cell, lymphoma lines. To analyze the expression of cytokine genes before and after EBV infection, transcripts of cytokines at different time intervals were measured according to the values of relative mRNA densities (Fig. 3). Before EBV infection, only insignificant basal levels of TNF- $\alpha$ transcripts were detected in parental or CR2-transfected T cell lymphoma lines H9 and HUT78. After

Table II. Cytokine Secretion in EBV-infected T and B Cell Lymphoma Lines at Different Time Points as Detected by ELISA Test

\begin{tabular}{|c|c|c|c|c|c|c|c|c|c|}
\hline \multirow[b]{2}{*}{ EBV infection } & \multicolumn{3}{|c|}{ TNF- $\alpha$} & \multicolumn{3}{|c|}{ IFN- $\gamma$} & \multicolumn{3}{|c|}{ IL-1 $1 \alpha$} \\
\hline & $0 \mathrm{~d}$ & $1 \mathrm{~d}$ & $3 \mathrm{~d}$ & $0 \mathrm{~d}$ & $1 \mathrm{~d}$ & $3 \mathrm{~d}$ & $0 \mathrm{~d}$ & $1 \mathrm{~d}$ & $3 \mathrm{~d}$ \\
\hline & $p g / m l$ & $p g / m l$ & $\mathrm{pg} / \mathrm{ml}$ & $\mathrm{pg} / \mathrm{ml}$ & $\mathrm{pg} / \mathrm{ml}$ & $p g / m l$ & $p g / m l$ & $p g / m l$ & $\mathrm{pg} / \mathrm{ml}$ \\
\hline \multicolumn{10}{|l|}{ H9 (10 cells $)$} \\
\hline Parental H9 line & 11.1 & 10.5 & 12.7 & 63.2 & 69.3 & 74.0 & 10.6 & 12.5 & 13.5 \\
\hline CR2-transfected H9 & 13.6 & 24.1 & 42.9 & 63.4 & 66.4 & 66.5 & 11.0 & 11.8 & 10.4 \\
\hline CR2-H9/UV-irradiated EBV & 14.1 & 14.7 & 12.8 & 67.0 & 61.1 & 69.9 & 10.0 & 10.0 & 11.3 \\
\hline \multicolumn{10}{|l|}{ HUT78 (10 cells $)$} \\
\hline Parental HUT78 line & 17.2 & 15.3 & 14.6 & 87.2 & 101.3 & 96.7 & 18.5 & 17.2 & 16.7 \\
\hline CR2-transfected HUT78 & 12.8 & 25.9 & 30.6 & 81.1 & 86.0 & 90.5 & 21.3 & 17.7 & 16.5 \\
\hline CR2-HUT78/UV-irradiated EBV & 14.4 & 17.0 & 18.5 & 66.2 & 88.9 & 70.5 & 14.5 & 14.6 & 18.9 \\
\hline \multicolumn{10}{|l|}{ B cell lines $\left(10^{6}\right.$ cells $)$} \\
\hline $\mathrm{BJ} A B$ & 2.7 & 1.5 & 2.2 & 40.3 & 44.5 & 36.8 & 10.0 & 12.1 & 13.5 \\
\hline MC116 & 1.5 & 1.7 & 1.5 & 35.4 & 27.4 & 26.3 & 1.0 & 1.0 & 1.1 \\
\hline
\end{tabular}

Release of TNF- $\alpha$, IFN- $\gamma$, and IL-1 $\alpha$ in EBV-infected CR2-transfected T cell lines H9 and HUT78 and B cell lines BJAB and MC116 at different time points. The cytokines in culture supernatants before EBV infection $(0 \mathrm{~d})$ and after $1 \mathrm{~d}$ and $3 \mathrm{~d}$ of EBV infection were determined by sandwich ELISA method. The CR2-negative parental T cell lines and UV-irradiated EBV infection of CR2-transfected lines were used as controls. Values among triplicate samples varied $\leq 10 \%$. 

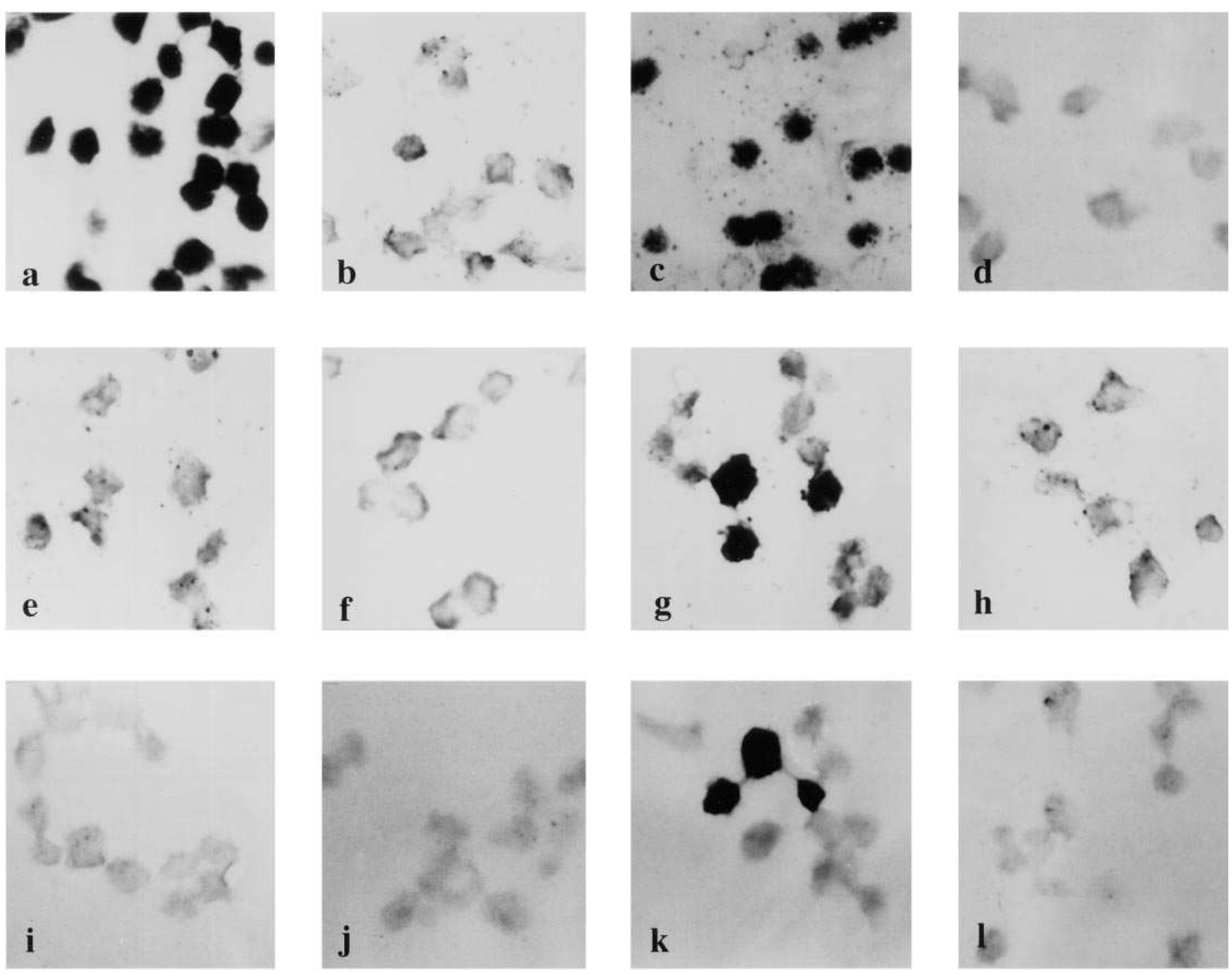

Figure 2. Successful in vitro infection of T cell lines with EBV was verified by in situ hybridization using EBER1 oligonucleotide probes. The intense black dot-like granules represent positive EBER1 transcripts detected in the nucleus of the positive control line B95.8 as seen in $a$. Control slides for B95.8 cells using sense oligonucleotide probe revealed no demonstrable EBER1 transcripts as seen in $b$. Other cell lines and probes are listed: $c$, EBV-infected BJAB cells, EBER1 probe; $d$, uninfected BJAB cells, EBER1 probe; $e$, parental H9 cells, EBER1 probes; $f$, uninfected CR2-transfected H9 cells, EBER1 probe; $g$, EBV-infected CR2-transfected H9 cells, EBER1 probe; $h$, EBV-infected CR2-transfected H9 cells, sense-strand probe; $i$, parental HUT78 cells, EBER1 probes; $j$, uninfected CR2-transfected HUT78 cells, EBER1 probe; $k$, EBV-infected CR2transfected HUT78 cells EBER1 probe; and $l$, EBV-infected CR2-transfected HUT78 cells, sense-strand probe.

EBV infection, enhanced (2.47-fold for $\mathrm{H} 9$, and 4.84-fold for HUT78) relative mRNA densities of $\mathrm{TNF}_{-} \alpha$ gene were observed on the first day of infection, and increased to 6.14 times (H9) and 7.25 times (HUT78), respectively, on the third day of infection. There was no detectable response of INF- $\gamma$ or IL- $1 \alpha$ genes to EBV infection in either cell line. For EBV-infected B cell lines, interestingly, a decreased (0.36-fold) relative mRNA density of TNF- $\alpha$ gene was observed in BJAB line after $3 \mathrm{~d}$ of EBV infection. Both B cell lymphoma lines showed unaltered expression on IFN- $\gamma$ and IL-1 $\alpha$ genes expression after EBV infection (Fig. 3).

Two additional control studies were performed to assure the specificity of the effect of EBV infection. We found no change of cytokine gene expression when the parental (CR2negative) $\mathrm{T}$ cell lines were exposed to EBV preparations, nor when the CR2-transfected $\mathrm{T}$ cell lines were exposed to UVinactivated virus.
Enhanced secretion of TNF- $\alpha$ by in vitro EBV infection of CR2-transfected $T$ cell, but not B cell, lymphoma lines. In agreement with the above RT-PCR data on virus-induced upregulation of the TNF- $\alpha$ gene, enhanced secretion of TNF- $\alpha$ was observed in EBV-infected CR2-transfected T cell lymphoma lines H9 and HUT78 as determined by ELISA test. As shown in Table II, there was negligible basal level secretion of TNF- $\alpha$ protein in T cell lymphoma lines H9 and HUT78 before EBV infection after adjusting for the background level of TNF- $\alpha$ in the culture medium. A significant increase of $\mathrm{TNF}_{-} \alpha$ secretion was observed in both CR2-transfected $\mathrm{T}$ cell lines (threefold for $\mathrm{H} 9$ and 2.4-fold for HUT78 on the third day after EBV infection). By contrast, no detectable change of IFN- $\gamma$ and IL- $1 \alpha$ levels was observed in either T cell line after EBV infection. In CR2-transfected T cells exposed to UV-inactivated virus as well, no apparent change in TNF- $\alpha$, IFN- $\gamma$, or IL- $1 \alpha$ secretion could be observed (Table II). Consistent with the data of cytokine 
CR2-H9

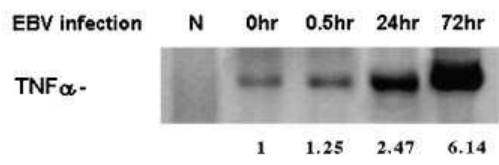

IFNY -

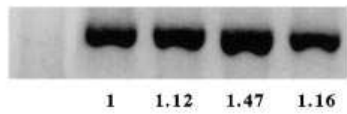

$\mathrm{IL} 1 \alpha-$

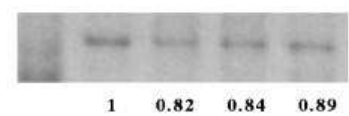

$\beta$-actin -
CR2-HUT78
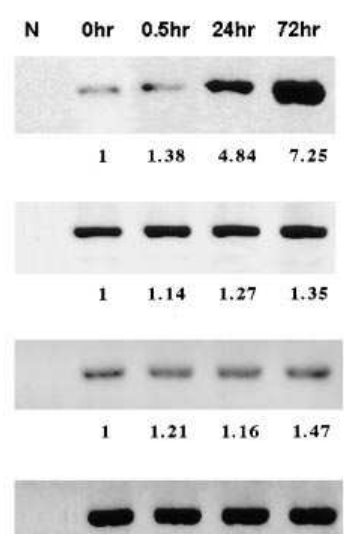

BJAB

N Ohr $0.5 \mathrm{hr} \quad 24 \mathrm{hr} \quad 72 \mathrm{hr}$
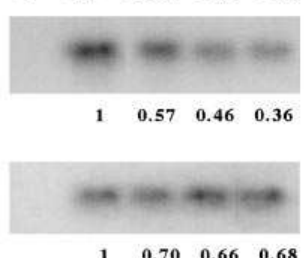

$1 \quad 0.70 \quad 0.66 \quad 0.68$

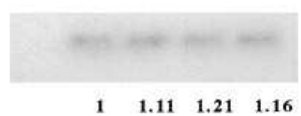

$\begin{array}{llll}1 & 1.11 & 1.21 & 1.16\end{array}$

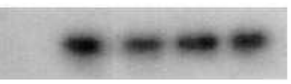

MC116
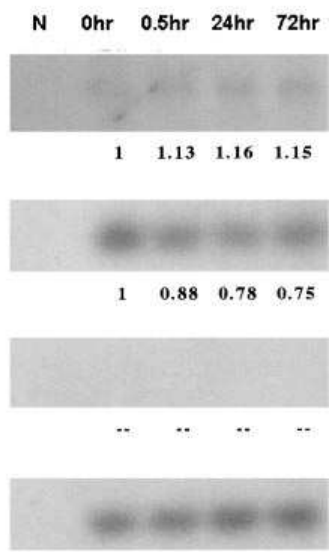

Figure 3. Transcripts of TNF- $\alpha$, IFN- $\gamma$, and IL- $1 \alpha$ genes in EBV-infected CR2-transfected T cell and B cell lines at different time points. Total RNAs were extracted from various cells before EBV infection ( 0 day) and after $30 \mathrm{~min}$, after $1 \mathrm{~d}$ and $3 \mathrm{~d}$ of EBV infection. The relative mRNA densities of each sample listed below are compared using the following formula: (OD of cytokine mRNA of the sample/OD of $\beta$-actin mRNA of the sample)(OD of cytokine mRNA of uninfected cells/OD of $\beta$-actin mRNA of uninfected cells). N, negative control, PCR reagents without DNA sample.

transcripts described above, there was also no detectable response or increased secretion of cytokines in either B cell lymphoma lines after EBV infection.

Enhanced phagocytosis and release of inflammatory cytokines in monocytic cell line U937 when treated with culture supernatants of EBV-infected CR2-transfected T cell lines. To clarify whether the specific infection of $T$ cells by EBV can lead to macrophage activation, a human monocytic cell line U937 was cocultured with supernatants from EBV-infected CR2-transfected H9 and HUT78 T cells. Monocytic cells treated with culture supernatant obtained from EBV-infected T cells $(0,24$, and $72 \mathrm{~h}$ of EBV infection) were thus screened in the phagocytosis assay (Figs. 4 and 5) and for cytokine secretion (Table III).

The unstimulated monocytic cells have a high nuclear/cytoplasmic ratio, smooth cell border, and absence of phagocytosis (Fig. $4 a$ ). After treatment with day 0 and day 3 culture super- natants of EBV-infected T cells, the monocytic cells showed clear evidence of phagocytosis, with engulfment of up to 10 100 fluorescent beads, and with ruffling of the cell border (Fig. $4, b$ and $c$ ). The percentage of phagocytotic cells could be assayed by flow cytometry as shown in Fig. 5. The U937 cells treated with day 0 culture supernatants of EBV-infected H9 cells revealed $9 \%$ phagocytotic activity (Fig. 5, A1). When treated with day 1 and day 3 culture supernatants, an increase of phagocytotic activity was observed (13\% and $21 \%$, respectively) (Fig. 5, $A 2$ and $A 3$ ).

In control studies, the U937 cells treated with culture medium RPMI-1640 alone showed inapparent phagocytotic activity $(<1 \%)$. In dose-response experiments using increasing concentrations of recombinant human $\mathrm{TNF}-\alpha$ as standards, an increase of phagocytotic activity ranging from $7 \%(9 \mathrm{ng} / \mathrm{ml}$ of rTNF- $\alpha$ ) to $12 \%$ and $15 \%$ (12 and $18 \mathrm{ng} / \mathrm{ml}$ of $\mathrm{rTNF}-\alpha$ ) was observed (Fig. 5, B1-B3).
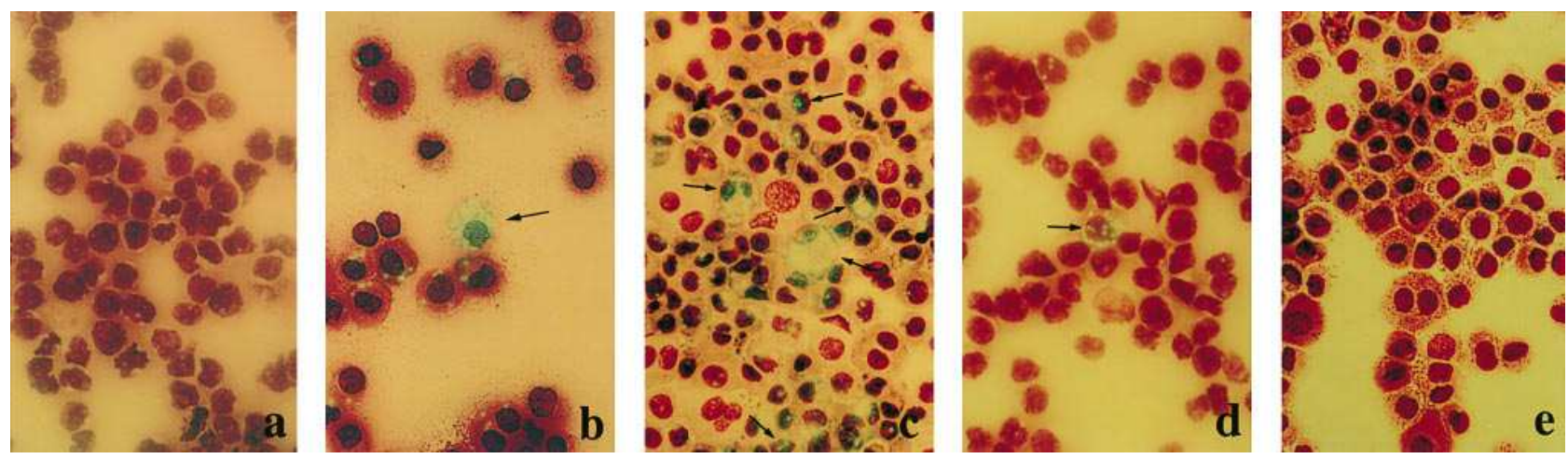

Figure 4. Morphology of phagocytosis in monocytic U937 cells. U937 cells were coincubated with FITC-labeled latex beads under different conditions: (a) untreated U937 cells; (b) U937 cells cocultured with culture supernatants of 0-day EBV-infected CR2-H9 cells; and (c) U937 cells cocultured with culture supernatants of 3-d EBV-infected CR2-H9 cells. (d) Phagocytotic activities of U937 cells observed in Fig. $c$ could be blocked by pretreatment of the culture supernatant of EBV-infected T cells with high-dosage $(50 \mu \mathrm{g} / \mathrm{ml})$ neutralizing anti-TNF- $\alpha$, and could be almost completely blocked by a combination of anti-TNF- $\alpha$ and anti-IFN- $\gamma$ (Fig. $e$ ). 


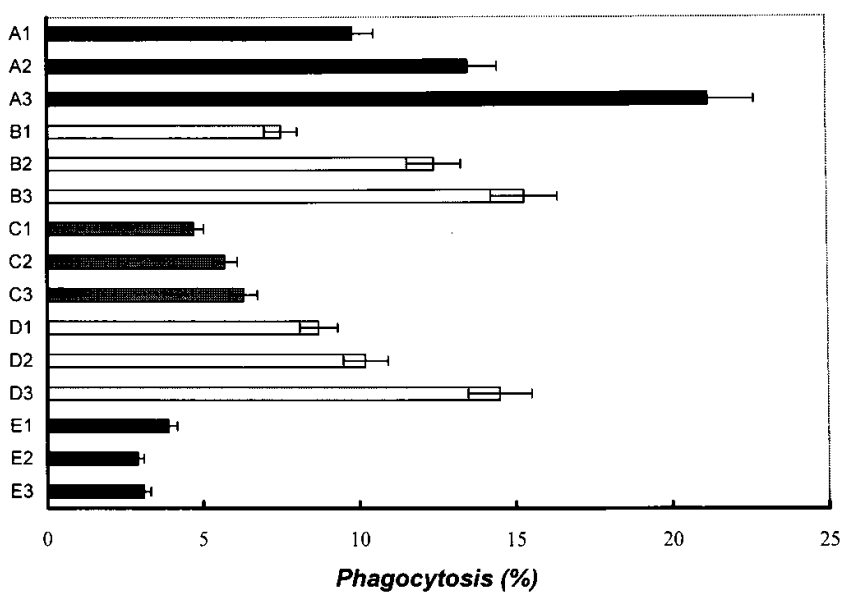

Figure 5. Assay of phagocytosis activity of U937 cells. The percentage of cells that engulfed FITC-labeled latex beads was counted by flow cytometry using a FACSort ${ }^{\mathrm{TM}}$ machine (Becton Dickinson Labware). (A) U937 cells pretreated with cultured supernatants of $0-\mathrm{d}$ (A1), 1-d (A2), and 3-d (A3) EBV-infected CR2-H9 cells. (B) U937 cells were directly treated with $8(B 1), 15(B 2)$, or $24 \mathrm{pg} / \mathrm{ml}(B 3)$ of recombinant TNF- $\alpha$ as standard controls of dose response of TNF- $\alpha$. (C) Blockade of phagocytosis activity as seen in A1-3 by a high dosage $(50 \mu \mathrm{g} / \mathrm{ml})$ of anti-TNF- $\alpha$ in culture supernatants of 0 -d $(C 1), 1-\mathrm{d}$ (C2), and 3-d (C3) EBV-infected CR2-H9 cells. D1-3, blockade of phagocytosis activity as seen in $A 1-3$ by a high dosage of anti-IFN- $\gamma$. E1-3, blockade of phagocytosis activity as seen in $A 1-3$ by high dosages of combined anti-TNF- $\alpha$ and anti-IFN- $\gamma$.

In parallel with the phagocytotic activity, the monocytic cells also showed increased secretion of TNF- $\alpha$, IFN- $\gamma$, and IL$1 \alpha$ as measured by ELISA (Table III). The basal level secretion of TNF- $\alpha$, IFN- $\gamma$ and IL- $1 \alpha$ in monocytic cell line U937 was low (TNF- $\alpha, 3.6 \mathrm{pg} / \mathrm{ml}$; IFN- $\gamma, 6.2 \mathrm{pg} / \mathrm{ml}$; and IL- $1 \alpha, 25.3 \mathrm{pg} /$ $\mathrm{ml}$ ). A $2-5$-fold increase of TNF- $\alpha$, IFN- $\gamma$, and IL- $1 \alpha$ secretion in U937 cells was observed when treated with culture supernatants of EBV-infected CR2-transfected H9 cells (Table III) and HUT78 cells (data not shown). In control studies, no change of monokine release was observed.

Blocking phagocytotic activity and monokine release by cytokine-specific antibodies. To determine whether the enhanced phagocytotic activity and cytokine release from mono- cytic cells was induced by specific cytokines secreted by EBVinfected T cells, the culture supernatant of EBV-infected T cells was pretreated with cytokine-neutralizing antibodies before addition to monocytic cells. Because IL- $1 \alpha$ transcripts were not detectable in T cell lymphoma tissues, and because IL- $1 \alpha$ was not upregulated by EBV in T cell lines in the above work, we concentrated on anti-TNF- $\alpha$ and anti-IFN- $\gamma$ for this antibody neutralization study. Preliminary experiments showed that the anti-TNF- $\alpha$ at $0.02 \mu \mathrm{g} / \mathrm{ml}$ and anti-IFN- $\gamma$ at $7 \mu \mathrm{g} / \mathrm{ml}$ could neutralize $50 \%$ of the biological activity of $0.25 \mathrm{ng} / \mathrm{ml}$ of $\mathrm{rTNF}-\alpha$, and $5 \mathrm{ng} / \mathrm{ml}$ of rIFN- $\gamma$, respectively, in a bioassay using L929 cells. As shown in Fig. 5 and Table III, induction of phagocytosis and monokine release in response to culture supernatants of EBV-infected T cells could be blocked by pretreatment of these supernatants with neutralizing anti-TNF- $\alpha$. A $70 \%$ increase of the phagocytotic activity induced by 3 -d supernatants of EBV-infected $\mathrm{H} 9$ cells could be blocked by high-dose (50 $\mu \mathrm{g} / \mathrm{ml}$ ) anti-TNF- $\alpha$ (Fig. 5, $A 3$ vs. $C 3$, morphology shown in Fig. $4 d)$. Anti-IFN- $\gamma(20 \mu \mathrm{g} / \mathrm{ml})$ only caused a $31 \%$ reduction (Fig. 5, $A 3$ vs. D3). Interestingly, activation of phagocytosis could be most strongly $(85 \%)$ blocked by a combination of anti-TNF- $\alpha$ and anti-IFN- $\gamma$ (Fig. 5, A3 vs. E3, morphology shown in Fig. $4 e$ ). Similar results were also observed using the culture supernatants of EBV-infected HUT78 cells (data not shown).

The inhibitory effects of neutralizing anti-TNF- $\alpha$ and antiIFN- $\gamma$ were also apparent in the suppression of monokine secretion. As shown in Table III, anti-TNF- $\alpha$ caused a 59-78\% blockade of the monokine secretion induced in U937 cells by treatment with 3-d supernatant of EBV-infected H9 cells. The effects of anti-IFN- $\gamma$ were lower (16-48\%), whereas a combination of anti-TNF- $\alpha$ and anti-IFN- $\gamma$ caused a $59-82 \%$ blockade. As a control, no apparent change of cell viability, phagocytotic activity, and cytokine secretion could be observed after direct coculture of these cytokine-specific antibodies with monocytic cells.

\section{Discussion}

The starting point for these studies was the clinical observation that a substantial percentage of patients with peripheral $\mathrm{T}$ and nasal T/NK cell lymphoma progress to fatal HS $(16,22,29)$. By comparison, HS is a relatively infrequent complication in patients with B cell lymphoma (30). We are particularly inter-

Table III. Monokine Secretion by U937 Cells Cocultured with Supernatants of EBV-infected CR2-H9 Cells at Different Time Points

\begin{tabular}{|c|c|c|c|c|c|c|c|c|c|c|c|c|c|c|c|c|}
\hline \multirow{4}{*}{$\begin{array}{l}\text { Treatments } \\
\text { anti-TNF- } \alpha \\
\text { anti-IFN- } \gamma\end{array}$} & \multicolumn{12}{|c|}{ Supernatants of EBV-infected CR2-H9 cells } & & & & \\
\hline & \multicolumn{4}{|c|}{$0 \mathrm{~d}$ infection } & \multicolumn{4}{|c|}{$1 \mathrm{~d}$ infection } & \multicolumn{4}{|c|}{$3 \mathrm{~d}$ infection } & \multicolumn{4}{|c|}{ Fresh medium } \\
\hline & - & + & - & + & - & + & - & + & - & + & - & + & - & + & - & + \\
\hline & - & + & - & + & - & + & - & + & - & + & - & + & - & + & - & + \\
\hline $\mathrm{TNF}-\alpha(\mathrm{pg} / \mathrm{ml})$ & 12.8 & 7.7 & 10.7 & 6.9 & 16.5 & 8.7 & 15.5 & 5.3 & 28.8 & 9 & 17.5 & 5 & 3.6 & 4.0 & 2.6 & 3.4 \\
\hline $\operatorname{IFN}-\gamma(\mathrm{pg} / \mathrm{ml})$ & 7 & 7.5 & 6.7 & 4.3 & 11.4 & 7.3 & 9.6 & 7.5 & 17.6 & 7.2 & 14.7 & 7.2 & 6.2 & 5.8 & 5.9 & 7.1 \\
\hline $\mathrm{IL}-1 \alpha(\mathrm{pg} / \mathrm{ml})$ & 45.3 & 36.4 & 29.2 & 27.5 & 111 & 58.6 & 67.6 & 46 & 256 & 57.5 & 148 & 55 & 25.3 & 22.2 & 21 & 29.5 \\
\hline
\end{tabular}

TNF- $\alpha$, IFN- $\gamma$, and IL-1 $\alpha$ production in monocytic U937 cells at different time intervals as detected by ELISA method. Secretion of monokines from the activated U937 cells was assayed in parallel as described in Fig. 5. Monokine secretion with or without anti-TNF- $\alpha$ and anti-IFN- $\gamma$ was examined and compared. Values among triplicate samples varied $\leq 10 \%$. 
ested in the fact that many of these $\mathrm{T}$ or $\mathrm{T} / \mathrm{NK}$ cell lymphomas are EBV genome-positive, raising the possibility that some specific factors or virus-induced cytokine secretion in EBVpositive $\mathrm{T}$ or $\mathrm{T} / \mathrm{NK}$ cells leads to inappropriate macrophage activation, and hence to HS. Our observations on in vivo tumor materials lend support to this view in that $\mathrm{TNF}-\alpha$ gene expression was much more frequently detected in EBV-positive $\mathrm{T}$ or $\mathrm{T} / \mathrm{NK}$ cell lymphomas than in other lymphomas studied. The hypothesis that TNF- $\alpha$ upregulation was EBV-induced was further supported by in vitro infection studies with two CR2-transfected $T$ cell lines, although it remains to be seen whether these findings with cell lines reflect the activity of EBV when the virus gains access to normal T cells. Studies using T/NK or NK cell lines are mandatory to clarify whether EBV will also play a similar role in upregulating cytokine genes in these cells.

Various types of inflammatory cytokines have been found to be elevated in HS patients (6-12), especially TNF- $\alpha$ and IL-1 $\alpha$ (12). More recently, IL-6, IFN- $\gamma$, and GM-CSF were also reported to be elevated in subsequent studies $(7,8,11,32)$. Foss et al. also demonstrated enhanced expression of TNF- $\alpha$, lymphotoxin, IL-1 $\alpha$, and IL- 6 genes in peripheral T cell lymphoma of angioimmunoblastic lymphadenopathy (AILD) type (32). Despite the range of cytokines so implicated, our studies suggest that $\mathrm{TNF}-\alpha$ is the major cytokine responsible for the subsequent development of HS in EBV-infected T lymphoproliferative disorders. The other cytokines or monokines may be secondary products derived not from $\mathrm{T}$ cells, but from activated macrophages. There are several lines of evidence to support this hypothesis. First, in this study EBV appears to upregulate the TNF- $\alpha$ gene selectively among the three types of cytokines examined. The remarkable suppression of macrophage activation and monokine release caused by treating culture supernatant of EBV-infected T cells with monoclonal anti-TNF- $\alpha$ further support this possibility. Although IFN- $\gamma$ transcripts could be detected in many $\mathrm{T}$ cell lymphoma tissues and cell lines $(7,31,32)$, IFN- $\gamma$ expression appears to be unrelated to the EBV status, and is not further inducible after EBV infection in vitro. Our study, however, suggests that IFN- $\gamma$ may synergize with $\mathrm{TNF}-\alpha$ to enhance macrophage activation under some circumstances. By contrast, IL- $1 \alpha$ is unlikely to be involved in EBV-associated HS, since IL-1 $\alpha$ transcripts were not detectable in EBV-infected $\mathrm{T}$ cell lymphoma tissues, nor could IL- $1 \alpha$ be upregulated by in vitro EBV infection of $\mathrm{T}$ cells. A second important line of evidence in favor of a role for $\mathrm{TNF}-\alpha$ is the close correlation between clinicopathologic features of HS and the biologic effects of TNF- $\alpha$ in animal models. The correlating factors include suppression of hematopoietic precursor cells (33), disturbances of lipid metabolism, and fatty change of the liver (34-36). Third, TNF- $\alpha$ has been shown to be the most important factor in macrophage activation during infection of murine cytomegalovirus, human herpes virus-6, and herpes simplex virus $(23,24,37-38)$. Finally, the level of $\mathrm{TNF}-\alpha$ has been reported to be an important indicator of prognosis in HS patients (12).

In this study, our observations on in vivo material generally support the finding from the in vitro model. Therefore, despite the heterogeneous sites of tumor presentation, enhanced TNF- $\alpha$ transcription was a relatively consistent feature in EBVinfected $\mathrm{T}$ and $\mathrm{T} / \mathrm{NK}$ cell lymphomas, whereas TNF- $\alpha$ expression in EBV-negative T cell lymphoma, EBV-associated B cell lymphoma, and EBV-negative B cell lymphoma was relatively low. All four cases presenting with HS in this series were EBVcontaining $\mathrm{T}$ and $\mathrm{T} / \mathrm{NK}$ cell lymphomas, and all showed enhanced TNF- $\alpha$ gene transcripts. Interestingly, by in situ hybridization, Foss et al. demonstrated that EBV-infected lymphoid cells do not express detectable TNF- $\alpha$ transcripts in AILD type T cell lymphoma (32). No AILD cases were included in this study, however, since AILD lesions usually contain a substantial amount of reactive lymphoid cells, making them unsuitable for RT-PCR analysis of gene expression. Furthermore, AILD lesions are fundamentally different from the situation in EBV-positive $\mathrm{T}$ and $\mathrm{T} / \mathrm{NK}$ cell lymphomas since in AILD, EBV predominantly infects B cells rather than T cells (32). This finding emphasizes the fact that EBV-associated lymphoproliferative conditions represent a range of pathologically distinct diseases.

Even within this study, the selective expression and secretion of TNF- $\alpha$ does not completely explain the final emergence of HS, since HS did not develop in all the cases of B and $\mathrm{T}$ cell lymphomas that expressed enhanced $\mathrm{TNF}-\alpha$ transcripts. Other cytokines, such as IFN- $\gamma$, IL-6, IL-10, and GM-CSF, may act synergistically with TNF- $\alpha$ to activate macrophages in HS patients $(7,8,11,31)$. This result is consistent with our finding that anti-TNF- $\alpha$ and anti-IFN- $\gamma$ can combine in blocking $\mathrm{T}$ cell-mediated macrophage activation. Such results imply that full-blown activation of macrophages as observed in HS may involve multiple cytokines, but with $\mathrm{TNF}_{-} \alpha$ playing a primary and major role.

Although this and many other studies have suggested that EBV plays an important role in the pathogenesis of HS (2, 3, $18,21,30)$, a few investigators emphasize that it is the $\mathrm{T}$ and T/NK cell origin of the lymphoma rather than the EBV positivity that is the predisposing factor (30). The current in vivo and in vitro studies strongly argue that both EBV positivity and $\mathrm{T}$ or $\mathrm{T} / \mathrm{NK}$ cell lineage are important. As described above, EBV plays a differential role in the regulation of cytokine gene expression in different cell types. The molecular mechanism by which EBV mediates differential regulation of cytokine production remains to be clarified. Analogous to HTLV-1 tax protein, several EBV-encoded transactivating proteins such as EBNA1-6, LMP-1, and BZLF-1 may upregulate cytokine genes (39-41). LMP1 has been shown to engage the signaling pathway and to mediate NFkB activation $(42,43)$. Our preliminary data revealed that the EBV-infected T cell line $\mathrm{H} 9$ selectively expressed EBNA1, LMP-1, and LMP2A, and that LMP-1 is likely to be responsible for the effect upon the TNF- $\alpha$ gene (J.D. Lay and I.J. Su, unpublished data).

Several therapeutic regimens have been designed to combat the cytokine effect in HS patients. An immunomodulation treatment incorporating etoposide and intravenous immunoglobulin has been reported to be effective in controlling hemophagocytic progression in a substantial percentage of HS patients both in our institution and in several others $(29,44$ 47). As an alternative approach, this study suggests that the inhibition of macrophage activation by anti-TNF- $\alpha$ will provide a potential immunotherapy to rescue the patients with this fatal syndrome. Heise et al. reported that in vivo administration of neutralizing anti-TNF- $\alpha$ and anti-IFN- $\gamma$ could inhibit macrophage activation during herpes simplex virus and cytomegalovirus infection in both normal and SCID mice (23). It will be important to determine whether such antibody-mediated blockade of specific cytokines will have clinical benefit in the context of EBV-associated HS. 


\section{Acknowledgments}

This research is supported by grants from the National Science Council and the National Health Research Institute, Taiwan (Dr. I.J. Su). Doctor Kadin receives support from the Beth Israel Pathology Foundation.

\section{References}

1. Risdall, R.J., R.W. McKenna, M.E. Nesbit, M. Kribit, H. Balfour, R. Simmons, and R.D. Brunning. 1979. Virus-associated hemophagocytic syndrome-A benign histiocytic proliferation distinct from malignant histiocytosis. Cancer. 44:993-1002.

2. Su, I.J., C.H. Wang, A.L. Cheng, and R.C. Chen. 1995 Hemophagocytic syndrome in Epstein-Barr virus-associated T-lymphoproliferative disorders. Disease spectrum, pathogenesis and management. Leuk. Lymphoma. 19:401-406.

3. Su, I.J., H.C. Hsieh, and C.Y. Lee. 1989. Histiocytic medullary reticulosis: a lethal form of primary EBV infection in young children in Taiwan. Lancet. 27:519.

4. Chen, R.L., I.J. Su, K.S. Lin, S.H. Lee, D.T. Lin, W.M. Chuu, K.S. Lin, L.M. Hung, and C.Y. Lee. 1991. Fulminant childhood hemophagocytic medullary reticulosis. Am. J. Clin. Pathol. 96:171-176.

5. Henter, J.L., G. Elinder, and A. Ost. 1991. The FHL study group of the histiocyte society diagnostic guidelines for hemophagocytic lymphohistiocytosis. Semin. Oncol. 18:29-33.

6. Simrell, C.R., J.B. Margolick, G.R. Crabtree, J. Cossman, A.S. Fauci, and E.S. Jaffe. 1985. Lymphokine-induced phagocytosis in angiocentric immunoproliferative lesions (AIL) and malignant lymphoma arising in AIL. Blood. 65: 1469-1476.

7. Ohga, S., A. Matsuzaki, M. Nishizaki, T. Nagashima, T. Kai, M. Suda, and K. Ueda. 1993. Inflammatory cytokines in virus-associated hemophagocytic syndrome: interferon gamma as a sensitive indicator of disease activity. Am. $J$. Pedi. Hema. Oncol. 15:291-298.

8. Henter, J.I., G. Elinder, O. Soder, M. Hansson, B. Anderson, and U. Anderson. 1991. Hypercytokinemia in familial hemophagocytic lymphohistiocytosis. Blood. 78:2918-2922.

9. Temeles, D.S., H.E. McGrath, E.L.W. Kitter, R.K. Shadduck, V.K. Kister, R.B. Crittenden, B.L. Turner, and P.J. Quensenberry. 1993. Cytokine expression from bone marrow derived macrophages. Exp. Hematol. (NY). 21:388-393.

10. Foss, H.D., H. Herbst, M. Hummel, I. Araujo, U. Latza, C. Rancso, F. Dallenbach, and H. Stein. 1994. Pattern of cytokine gene expression in infectious mononucleosis. Blood. 83:707-712.

11. Imashuku, S., S. Hibi, F. Fujiwara, S. Ikushima, and S. Toso. 1994. Haemophagocytotic lymphohistiocytosis, interferon-gamma-naemia and EpsteinBarr virus involvement. Brit. J. Haematol. 88:656-658.

12. Ishii, E., S. Ohga, T. Aoki, S. Yamada, M. Sako, H. Tasaka, A. Kuwano, M. Sasaki, Y. Tsunematsu, and K. Ueda. 1991. Prognosis of children with virusassociated hemophagocytic syndrome and malignant histiocytosis: correlation with levels of serum interleukin-1 and tumor necrosis factor. Acta Haematol. (Basel). 85:93-99.

13. Ng, C.S., J.K.C. Chan, P.N.M. Cheng, and S.C. Szeto. 1986. Nasal T-cell lymphoma associated with hemophagocytic syndrome. Cancer. 58:67-71.

14. Craig, F.E., C.N. Clare, J.L. Sklar, and P.M. Banks. 1992. T cell lymphoma and the virus-associated hemophagocytic syndrome. Am. J. Clin. Pathol. 97:189-194.

15. Falini, B., S. Pileri, I. de Solas, M.F. Martell, D.Y. Mason, G. Delsol, K.C. Gatter, and M. Fagioli. 1990. Peripheral T-cell lymphoma associated with hemophagocytic syndrome. Blood. 75:434-444.

16. Su, I.J., Y.H. Hsu, M.T. Lin, A.L. Cheng, C.W. Wang, and L.M. Weiss. 1993. Epstein-Barr virus-containing T cell lymphoma presents with hemophagocytic syndrome mimicking malignant histiocytosis. Cancer. 72:2019-2027.

17. Su, I.J., H.C. Hsieh, K.H. Lin, W.C. Uen, C.L. Kao, C.L. Chen, A.L. Cheng, M.E. Kadin, and J.Y. Chen. 1991. Aggressive peripheral T cell lymphoma containing Epstein-Barr virus DNA: a clinicopathological and molecular analysis. Blood. 77:799-808.

18. Su, I.J., R.L. Chen, D.T. Lin, K.S. Lin, and C.C. Chen. 1994. EpsteinBarr virus (EBV) infects T lymphocytes in childhood EBV-associated hemophagocytic syndrome in Taiwan. Am. J. Pathol. 144:1219-1225.

19. Tsoukas, C.D., and J.D. Lambris. 1993. Expression of EBV/C3d receptors on T cells: biological significance. Immunol. Today. 14:56-59.

20. Watry, D., J.A. Hedrick, S. Siervo, G. Rhodes, J.J. Lamberti, J.D. Lambris, and C.D. Tsoukas. 1991. Infection of human thymocytes by Epstein-Barr virus. J. Exp. Med. 173:971-980.

21. Kawaguchi, H., T. Kiyashita, H. Herbst, G. Niedobitek, M. Asada, M. Tsuchida, R. Hanada, A. Kinoshita, M. Sakurai, N. Kobayashi, and S. Mizutani. 1993. Epstein-Barr virus-infected T lymphocytes in Epstein-Barr virus-associated hemophagocytic syndrome. J. Clin. Invest. 92:1444-1450.

22. Jaffe, E.S., J.K.C. Chan, I.J. Su, G. Frizzera, S. Mori, A.C. Feller, and C.S. Ho. 1996. Report of the workshop on nasal and related extranodal angiocentric T/natural killer cell lymphomas. Definitions, differential diagnosis, and epidemiology. Am. J. Surg. Pathol. 20:103-111.

23. Heies, M.T., and H.W. Virgin IV. 1995. The T-cell-independent role of gamma-interferon and tumor necrosis factor alpha in macrophage activation during murine cytomegalovirus and herpes simplex virus infection. J. Virol. 69: 904-909.

24. Geist, L.J., M.M. Monick, M.F. Stinski, and G.W. Hunninghake. 1994. The immediate early genes of human cytomegalovirus upregulate tumor necrosis factor gene expression. J. Clin. Invest. 93:474-478.

25. Baranji, K., L. Baranyi, T. Yoshida, N. Okada, and H. Okada. 1994. A low molecular weight phagocytosis-inhibitory factor obtained from human erythrocyte membranes specifically down-regulates Mac-1 activity on tetradecanoyl phorbol acetate-stimulated monocytic cell lines in a $\mathrm{Ca} 2+$-dependent manner. J. Immunol. 153:1724-1735.

26. Kao, Y.F., T.Y. Hsu, M.Y. Liu, J.Y. Chen, and C.S. Yang. 1993. Infection of CR2-expressing human epithelial cells with Epstein-Barr virus. In Epstein-Barr Virus and Associated Disease. T. Tursz, J.S. Pagano, D.V. Ablashi, G. de The, and G.R. Pearson, editors. John Libbey Eurotext/John Libbey Co. Ltd., Montrouge, London. 177-182.

27. Gaffey, M.J., H.F. Frierson, L.J. Medeiros, and L.M. Weiss. 1993. The relationship of Epstein-Barr virus to infection-related (sporadic) and familial hemophagocytosis: an in situ hybridization study. Hum. Pathol. 24:657-667.

28. Chomczynski, P., and N. Sacchi. 1987. Single-step method of RNA isolation by acid guanidinium thiocyanate-phenol-chloroform extraction. Anal. Biochem. 162:156-159.

29. Yao, M., A.L. Cheng, I.J. Su, M.T. Lin, W.C. Uen, H.F. Tien, C.H. Wang, and Y.C. Chen. 1994. Clinicopathologic spectrum of hemophagocytic syndrome in Epstein-Barr virus-associated peripheral T cell lymphoma. $B r . J$. Haematol. 87:535-543.

30. Wong, K.F., J.K.C. Chan, E.S.F. Lo, and C.S.C. Wong. 1996. A study of the possible etiologic association of Epstein-Barr virus with reactive hemophagocytic syndrome in Hong Kong Chinese. Hum. Pathol. 27:1239-1242.

31. Akashi, K., S. Hayashi, H. Gondo, S.I. Mizuno, M. Harada, K. Tamura, K. Yamasaki, T. Shibura, N. Uike, T. Okamura, et al. 1994. Involvement of interferon-gamma and macrophage-stimulating factor in pathogenesis of hemophagocytic lymphohistiocytosis in adults. Br. J. Haematol. 87:243-250.

32. Foss, H.D., I. Anagnostopoulos, H. Herbst, K. Ziemann, M. Hummel, and H. Stein. 1995. Patterns of cytokine gene expression in peripheral T-cell lymphoma of angioimmunoblastic lymphadenopathy type. Blood. 85:28622869.

33. Rusten, L.S., E.B. Smeland, F.W. Jacobsen, E. Lien, W. Lesslauer, H. Loetscher, C.M. Dubois, and E.W. Facobsen. 1994. Tumor necrosis factoralpha inhibits stem cell factor-induced proliferation of human bone marrow progenitor cells in vitro. J. Clin. Invest. 94:165-172.

34. Mizuhara, H., E. O'Neill, N. Seki, T. Ogawa, C. Kusunoki, K. Otsuka, S. Satoh, M. Niwa, H. Senoh, and H. Fujiwara. 1994. T cell activation-associated hepatic injury: mediation by tumor necrosis factor and protection by interleukin-6. J. Exp. Med. 179:1529-1537.

35. Feingold, K., M. Soued, I. Staprans, L.A. Gavin, M.E. Donahue, B.J. Huang, A.J. Moser, R. Gulli, and C. Grunfeld. 1989. Effect of tumor necrosis factor (TNF) on lipid metabolism in the diabetic rat: evidence that inhibition of adipose tissue lipoprotein lipase activity is not required for TNF-induced hyperlipidemia. J. Clin. Invest. 83:1116-1121.

36. Oliff, A., D. Defeo-Jones, M. Boyer, D. Martinez, D. Kiefer, G. Vuocolo, A. Wolfe, and S.H. Socher. 1987. Tumors secreting human TNF/cachectin induce cachexia in mice. Cell. 50:555-563.

37. Gosselin, J., L. Flamand, M. D'Addario, J. Hiscott, and J. Menezes. 1992. Infection of peripheral blood mononuclear cells by herpes simplex and Epstein-Barr viruses: differential induction of interleukin 6 and tumor necrosis factor- $\alpha$. J. Clin. Invest. 89:1849-1856.

38. Probert, L., J. Keffer, P. Corbella, H. Cazlaris, E. Patsavoudi, S. Stephens, E. Kaslaris, D. Kioussis, and G. Kollias. 1993. Wasting, ischemia and lymphoid abnormalities in mice expressing $\mathrm{T}$ cell targeted human tumor necrosis factor trangenes. J. Immunol. 151:1894-1906.

39. Kieff, E., and D. Leibowitz. 1991. The Epstein-Barr virus and its replication. In Fundamental Virology. B.N. Fields and D.M. Knipe, editors. Raven Press Ltd., New York. 168-194.

40. Wang, F., C.D. Gregory, M. Rowe, A.B. Rickinson, D. Wang, M. Birkenbach, H. Kikutani, T. Kishimoto, and E. Kieff. 1987. Epstein-Barr virus nuclear antigen 2 specifically induces expression of the $\mathrm{B}$ cell activation antigen CD23. Proc. Natl. Acad. Sci. USA. 84:3452-3456.

41. Peng, M., and E. Lundgren. 1993. Transient expression of the EpsteinBarr virus LMP1 gene in B-cell chronic lymphocytic leukemia cells, T cells, and hematopoietic cell lines: cell-type-independent-induction of $\mathrm{CD} 23, \mathrm{CD} 21$, and ICAM-1. Leukemia (Baltimore). 7:104-112.

42. Huen, D.S., S.A. Henderson, D. Croom-Carter, and M. Rowe. 1995. The Epstein-Barr virus latent membrane protein-1 (LMP1) mediates activation of NF-( $\mathrm{\kappa B}$ and cell surface phenotype via two effector regions in its carboxylterminal cytoplasmic domain. Oncogene. 10:549-560.

43. Mosialos, G., M. Birkenbach, R. Yalamanchili, T. VanArsdale, C. Ware, and E. Kieff. 1995. The Epstein-Barr virus transforming protein LMP1 engages signaling proteins for the tumor necrosis factor receptor family. Cell. 80:389-399.

44. Ambruso, D.R., T. Hays, W.F. Zwartjes, D.G. Tubergen, and B.E. Fa- 
vara. 1980. Successful treatment of lymphohistiocytosis with epipidophyllotoxin VP-16. Cancer. 45:2516-2520.

45. Brown, R.E., W.P. Bowman, C.A. D'Cruz, T.E. Pick, and J.E. Champion. 1987. Endoperoxidation, hyperprostaglandinemia, and hyperlipidemia in a case of erythrophagocytotic lymphohistiocytosis. Reversal with VP-16 and indomethacin. Cancer. 60:2388-2393.
46. Nydegger, U.E. 1992. Intravenous immunoglobulin in combination with other prophylactic and therapeutic measures. Transfusion (Phila.). 32:72-82.

47. Chen, R.L., K.H. Lin, D.T. Lin, I.J. Su, L.M. Huang, P.I. Lee, K.H. Hseih, K.S. Lin, and C.Y. Lee. 1995. Immunomodulation treatment for childhood virus-associated hemophagocytic lymphohistiocytosis. Br. J. Haematol 89:282-290. 